\title{
The relationship between category typicality and concept familiarity: Evidence from Spanish- and English-speaking monolinguals
}

\author{
PAULA J. SCHWANENFLUGEL \\ University of Georgia, Athens, Georgia \\ and \\ MARIO REY \\ Florida Atlantic University, Boca Raton, Florida
}

\begin{abstract}
We examined the relationship between an item's familiarity and its category typicality, employing ratings obtained from Spanish-and English-speaking monolinguals living in southern Florida. In the first experiment, Spanish- and English-speaking monolinguals were asked to rate the prototypicality of instances of 12 common language categories. The correlations between the Spanish and English speakers' rated item typicality indicated that the prototypicality gradients of the Spanish and English monolinguals were fairly discrepant for a number of categories. In the second experiment, we examined the degree to which these differences in cultural typicality could be accounted for by differences in rated cultural familiarity. It was predicted that, if familiarity plays a role in determining cultural differences in prototypicality, statistically controlling for the effects of cultural familiarity should result in higher interlingual typicality correlations. This should be true particularly for those categories for which there is a wide discrepancy in the typicality gradients for the two language groups. These predictions were confirmed. Consequently, we conclude that item familiarity is at least one variable influencing cultural differences in category typicality gradients.
\end{abstract}

Membership in a category is not an all-or-none thing. Rather, some members are judged to be more typical, better examples of a category than others (see Medin \& Smith, 1984; Mervis \& Rosch, 1981 for reviews). For example, shirt is generally viewed to be a better example of the category "clothing" than shawl is. Item typicality is correlated with how quickly people determine whether the particular item is a member of the designated category (see McCloskey \& Glucksberg, 1979; Smith, Shoben, \& Rips, 1974). Typicality is also related to ease of encoding items into memory for free recall in adults (Greenberg \& Bjorklund, 1981; Keller \& Kellas, 1978) and in children (Bjorklund \& Thompson, 1983). Children appear to learn categorical relationships for typical members of a category prior to atypical ones (Duncan \& Kellas,

\footnotetext{
We thank the participants who volunteered their time to help us complete this work. We especially thank J. Ben-Moleh, who helped us contact the large number of Spanish monolinguals who participated in this study, and C. Huberty, for providing valuable statistical advice. We appreciate the helpful comments that D. Bjorklund, H. Hock, A. Glass, and an anonymous reviewer gave us on other versions of this paper, and we thank S. McDonough for her secretarial help in typing the Appendix. Much of the research described in this paper was presented at the July 1985 meeting of the 20th Interamerican Congress of Psychology in Caracas, Venezuela. Requests for reprints should be addressed to Paula J. Schwanenflugel at the Department of Educational Psychology, University of Georgia, Athens, GA 30602.
}

1978; Posnansky, 1978). Adults are likely to name typical prior to atypical members of a category in listing members of categories (Glass \& Holyoak, 1975; Rosch \& Mervis, 1975). Thus, typicality seems to be a fundamental variable for examining the organization of members within categories.

Several explanations have been offered for why category members differ in perceived typicality. Rosch and Mervis (1975) argued that typicality is a function of the overall similarity of a category member to other members of the category and its dissimilarity to members of other categories. Smith et al. (1974) and McCloskey and Glucksberg (1979) defined typicality as a reflection of the similarity of members to a summary category concept representation. According to Glass and Holyoak (1975), typicality gradients are a function of the degree to which members are associated with their category concept. According to Medin and Schaffer (1978), typicality is related to the number of category versus noncategory members retrieved by a subject when he/she is presented with a member of the category.

Recently, there has been some debate concerning whether familiarity plays a role in determining typicality gradients. Rosch, Simpson, and Miller (1976) and Mervis, Catlin, and Rosch (1976) did not find evidence for frequency determinants of typicality. Using word frequency as a measure of familiarity, Mervis et al. (1976) found no correlation between familiarity and typicality. 
However, McCloskey (1980) found virtually no correlation between rated familiarity and word frequency. Using frequency of presentation for exemplars of artificial categories as a measure of familiarity, Rosch et al. (1976) found no effect of familiarity on typicality ratings when frequency was pitted against family resemblance. Barsalou (1985) recently criticized this procedure, noting that this method was incapable of detecting possible simultaneous effects of family resemblance and familiarity. Thus, neither of these studies is definitive in deciding the issue of whether familiarity influences the typicality gradients of categories.

Several other investigators have found more positive evidence regarding the role of familiarity in determining item typicality. Ashcraft (1978) and Malt and Smith (1982) argued that low typicality may be due in part to the possibility that individuals know less about or are less familiar with atypical than typical members of categories. They found that subjects tended to produce fewer properties for atypical than typical members of categories. However, the procedures employed by these experimenters may not have been sensitive enough to determine the role of familiarity in determining typicality. In both of these studies, the finding of fewer generated properties for atypical items may have been a result of having subjects list properties for a large number of instances of each of the categories examined. In writing down the features for a particular member, subjects may have remembered the features of the last category item for which properties were generated and may have spent less time accessing and verbally encoding those features again. If it is true that atypical exemplars share fewer features with other category members than typical exemplars, then the encoding of the properties for these atypical exemplars should be differentially hurt by the repetition of the category members in the set. For example, if the properties of robin had just been listed, then the properties for bluejay should be easily retrieved and verbally encoded but those of penguin should not. This alternative explanation gains credibility from the finding that there was no difference in the number of features listed for typical and atypical exemplars when Rosch and Mervis (1975) had subjects list features for only one example from each category. Thus, the results from the property-listing studies are inconclusive with regard to whether atypical items are generally less familiar than typical ones.

Other experimenters have used imageability as a measure of familiarity in determining the relationship between typicality and familiarity. Glass and Meany (1978) argued that there are probably two kinds of atypical instances of categories: familiar atypical and unfamiliar atypical. Thus, duck may be a familiar, although atypical, bird in terms of property overlap with other category members, whereas grackle is atypical only due to its relative unfamiliarity, even though its properties are quite typical of other birds. In order to test this idea experimentally, Glass and Meany had subjects rate instances on imageability, assuming that unfamiliar instances of a category would be less imageable than familiar instances. (This method of determining familiarity is also questionable. For example, embarrassment may be a familiar and typical exemplar of the category "emotion," but may be as hard to image as chagrin, which is an unfamiliar and atypical exemplar of "emotion." However, this method was not a problem with the relatively concrete items used by Glass and Meany.) Glass and Meany found that unfamiliar atypical exemplars were actually categorized more quickly than familiar atypical exemplars. This unexpected finding would not be predicted by a model that states that typicality is a direct reflection of familiarity, inasmuch as there is now a large body of literature suggesting that atypical instances are categorized more slowly than typical ones.

Several studies have examined the role of familiarity in various category tasks by having subjects rate instances of categories on their relative familiarity. McCloskey (1980) found correlations between familiarity and instance-categorization time ranging from -.49 to -.26 . Hampton and Gardiner (1983) found correlations of familiarity with rated typicality ranging from .82 to .27 , and of familiarity with category-instance association frequency ranging from -.85 to -.35 . On the other hand, for taxonomic categories, Barsalou (1985) found a correlation of only .19 between typicality and rated familiarity. Thus, the relationship between rated familiarity and typicality is not at all clear.

Due to the fair degree of disagreement among researchers as to whether familiarity influences the relative typicality of various instances of categories, we decided to further examine the relationship between familiarity and typicality. Specifically, we were interested in examining this issue interculturally by employing two Floridian subcultures, namely, Spanish monolinguals and English monolinguals living in South Florida. By determining the relationship between familiarity and typicality in these two groups, we could also ascertain whether the relative cultural familiarity of instances is related to the degree of potential differences in the typicality gradients for these groups.

Two experiments were required in order to examine the relationship between typicality and familiarity in English and Spanish monolinguals. In Experiment 1, typicality ratings for instances of 12 categories were obtained from each of these language groups. In Experiment 2, familiarity ratings were obtained so that the relationship between familiarity and typicality could be compared both interculturally and intraculturally. Also, to our knowledge there are no existing typicality or familiarity norms for Spanish-speaking Americans. Because Spanish-speaking Americans are becoming a greater proportion of the population of the United States, we felt that the availability of such norms might be of use to investigators studying comparative semantics and related topics. Thus, the present series of studies had both theoretical and practical aims. 


\section{EXPERIMENT 1}

In order to examine the possible relationship between instance familiarity and differences in the prototypicality gradients of the Spanish- and English-speaking monolinguals living in South Florida, it was necessary to first establish that such differences existed. Some previous crosscultural research had led us to question whether prototypicality gradient differences would be found in two such similar cultures. Employing two highly divergent cultures, Cole, Gay, Glick, and Sharp (1971) found a marked convergence between members of the Kpelle and American cultures in sorting patterns and similarity judgments for highly familiar exemplars of four categories. Similarly, members of the Dani culture found prototypical exemplars easiest to learn for the categories of color, geometric shape, and human facial expression, even though there were no Dani terms for some of the exemplars employed to teach the categories (Heider, 1972; Rosch, 1975b). Berlin and Kay (1969) noted that no language currently appears to have more than 11 basic color terms, and that the focal points of these terms are also universal. Hampton and Gardiner (1983) compared their English subjects' ratings of typicality to those of Rosch's (1975a) American participants and found a .85 correlation between the ratings of these two groups. Thus, there seemed at least some reason to doubt that there would be differences in the prototypicality gradients employed by the Spanish and English speakers used in our study.

In contrast to these findings of cultural similarity in categorization, Barsalou and Sewell (1984) asked American participants to take the points of view of members of African, American, Chinese, and French cultures; they found that subjects gave different but reliable typicality ratings for members of various taxonomic categories, depending on the point of view taken. Therefore, it seemed possible that actual differences in typicality gradients might be obtained for actual members of different cultural groups. Consequently, we asked Spanish- and English-speaking monolinguals to rate the prototypicality of instances of 12 categories.

\section{Method}

Subjects. The subjects were 100 South Florida residents, 50 native English-speaking monolinguals (23 males) and 50 native Spanish-speaking monolinguals ( 23 males), who were unpaid volunteers. The mean length of residence in Florida was 16.4 years for the Spanish speakers and 14.9 years for the English speakers. The Spanish speakers in this study were all of South and Central American origin.

Stimuli. The 12 semantic categories employed in the study were selected from the sample of 28 used by Uyeda and Mandler (1980). The categories were "bird," "part of a building," "cloth," "clothing," "color," "fruit," "furniture," "part of the human body," "'metal," "'musical instrument," "vehicle," and "weapon." These categories were selected to represent an assortment of category types ranging from man-made and biological taxonomies to part-whole relationships, as well as a more physiologically based domain (color). We also felt that these categories were relevant to both groups of subjects. Furthermore, Uyeda and Mandler's category items were either included or deleted depending upon whether a precise semantic equivalent existed for both language groups (i.e., whether the use of each term had similar extensions in both languages). Items not originally included in the Uyeda and Mandler norms were added to make the norms more extensively describe the range of exemplars familiar to South Florida residents. The items from these norms were translated into a Spanish-American, rather than Castilian, dialect, so as to properly reflect the idiom of our particular subjects.

Procedure. Two sets of test booklets were created, one in Spanish and the other in English. Each booklet contained 12 categories, each printed on a separate sheet with the name of the category printed at the top and the list of instances underneath. These sheets were randomized and stapled so that different subjects received different orderings of categories. The instructions for the English-speaking subjects were taken directly from Rosch (1975a), with the exception that the poles on Rosch's 1 to 7 scale were reversed so that a rating of 7 now represented a good example of a category. These instructions were translated into Spanish for the Spanish-speaking subjects as follows:

Clasifique en una escala del 1 al 7, la calidad de cada artículo presentado como ejemplar de su categoría correspondiente. Por ejemplo, si usted estima que una papa es el prototípico ejemplar de un "vegetal" (la categoría), pues anote un 7. Si tal vez usted estima que perejil es un ejemplo poco representativo del concepto "vegetal," entonces anote un 1 o un 2. Es decir, algunos artículos son más adecuados que otros como ejemplares de ciertas categorías, y su tarea será determinar la calidad de cada artículo como el prototípico ejemplar de dicha categoría.

"Prototípico ejemplar" no implica frecuencia, preferencia ni gusto personal. Utilizando el mismo ejemplo presentado en el párrafo anterior, a usted tal vez no le gusta comer papa, y más disfruta el sabor del perejil, y por lo tanto lo compra y lo utiliza con más frecuencia que la papa, pero quizás usted no considera perejil como un buen ejemplo conteniendo todas las caracteristicas del concepto "vegetal," resultando en un 1 o un 2 para ese artículo.

Todas las categorías y los artículos presentados en esta prueba son nombres concretos (lápiz, pelota, árbol, etc.). Si el significado de algún artículo le es desconocido, entonces anote un cero (0).

\section{Results and Discussion}

The mean prototypicality ratings, along with their associated standard deviations, can be found in the Appendix. The instances of the category are listed in descending rank order of typicality for each language. The rank order for the alternative language set is indicated in parentheses.

In order to determine the degree of convergence between the Spanish and English speakers' typicality gradients, Pearson product moment correlations of the mean typicality ratings for the English-Spanish translations were calculated. These can be seen in the first column of Table 1. Although the correlations between the English and Spanish typicality ratings were significant for 11 out of 12 of the categories employed, there was enough divergence in the ratings of the two language groups to suggest different typicality gradients for a number of the categories. The correlation between the Spanish and English ratings ranged from .16 (for "bird") to .94 (for "part of the human body"). When all the categories were pooled for a single analysis, there was an overall correlation between the Spanish and English speakers' typicality ratings of $.64(p<.05)$. Thus, the results of this study suggest that convergent typicality gradients cannot be assumed for these two similar cultures even though 
Table 1

Correlations for Experiments 1 and 2

\begin{tabular}{|c|c|c|c|c|c|}
\hline Category & $\begin{array}{l}\text { Interlingual } \\
\text { Rated } \\
\text { Typicality }\end{array}$ & $\begin{array}{l}\text { Interlingual } \\
\text { Rated } \\
\text { Familiarity }\end{array}$ & $\begin{array}{l}\text { English } \\
\text { Rated Typicality } \\
\text { with Familiarity }\end{array}$ & $\begin{array}{l}\text { Spanish } \\
\text { Rated Typicality } \\
\text { with Familiarity }\end{array}$ & $\begin{array}{c}\text { Interlingual } \\
\text { Rated Typicality } \\
\text { (Familiarity removed) }\end{array}$ \\
\hline Part of the Human Body & $.94^{*}$ & $.57^{*}$ & $.45^{*}$ & $.42^{*}$ & $.85^{*}$ \\
\hline Metal & $.89 *$ & $.86^{*}$ & $.71^{*}$ & $.91^{*}$ & $.46^{*}$ \\
\hline Weapon & $.89 *$ & $.46^{*}$ & -.01 & -.26 & $.88^{*}$ \\
\hline Clothing & $.89^{*}$ & $.39 *$ & $.52^{*}$ & $.60^{*}$ & $.83^{*}$ \\
\hline Cloth & $.73^{*}$ & $.62^{*}$ & $.83^{*}$ & $.82 *$ & $.69 *$ \\
\hline Color & $.72 *$ & $.85^{*}$ & $.82 *$ & $.73^{*}$ & $.47 *$ \\
\hline Vehicle & $.70^{*}$ & .22 & $.36^{*}$ & $.77^{*}$ & $.65^{*}$ \\
\hline Part of a Building & $.66^{*}$ & $.57^{*}$ & $.37 *$ & $.40^{*}$ & $.67 *$ \\
\hline Furniture & $.59^{*}$ & $.39^{*}$ & $.36^{*}$ & $.43 *$ & $.70^{*}$ \\
\hline Musical Instrument & $.54^{*}$ & .21 & $.70^{*}$ & $.66^{*}$ & $.66^{*}$ \\
\hline Fruit & $.52 *$ & .27 & $.88^{*}$ & $.50^{*}$ & $.71 *$ \\
\hline Bird & .16 & $.39^{*}$ & .12 & $.68^{*}$ & $.56^{*}$ \\
\hline Overall & $.64^{*}$ & $.48^{*}$ & $.50^{*}$ & $.47^{*}$ & $.73^{*}$ \\
\hline
\end{tabular}

there is considerable overlap between the two cultures in the extension of the category terms to instances of the category.

Reliabilities for the mean item ratings were calculated by correlating item means for the odd- and even-numbered Spanish- and English-speaking monolinguals. As can be seen in Table 2, the resulting reliabilities were uniformly high for both groups.

Another measure of cross-cultural differences in category structure is the number of shared highly prototypical instances for each of the categories. The number of cross-culturally shared prototypical instances (defined as the number of similar items in the top five rankings for each category) ranged from 1 (for "bird") to 5 (for "part of the human body" and "clothing"), with a mean of 3.58 shared prototypical instances. Rosch (1975a) argued that the tendency to structure categories in terms of prototypes and distance from prototypes forms a universal of human categorization. If this is the case, then there should be a strong convergence in the typicality gradients for those categories for which the language groups share similar prototypical exemplars. In order to examine this concept, we computed a correlation between the number of cross-culturally similar items of the five most prototypical exemplars for each category and the interlingual typicality correlations for the categories. Rosch's view would claim that when the best examples of each category are similar (as for "part of the human body"), it follows that the typicality gradients should be highly correlated, inasmuch as typicality might be considered a function of distance from the prototype(s). In contrast, when the prototypical exemplars for the two cultures differ (as for "bird"), then one should expect the typicality gradients to differ considerably. The correlation between the number of shared prototypical exemplars and the interlingual typicality correlation was $r(10)=.74(\mathrm{p}<.01)$. Consequently, this study provides evidence for the view that typicality gradients of two cultures can be expected to vary to the degree that the cultural prototypes differ. Thus, one component of cross-cultural differences in typicality judgments may be cultural differences in category prototypes.

Table 2

Reliabilities for the Item Ratings for Experiments 1 and 2

\begin{tabular}{|c|c|c|c|c|}
\hline Category & $\begin{array}{c}\text { Spanish } \\
\text { Rated } \\
\text { Typicality }\end{array}$ & $\begin{array}{l}\text { English } \\
\text { Rated } \\
\text { Typicality }\end{array}$ & $\begin{array}{c}\text { Spanish } \\
\text { Rated } \\
\text { Familiarity }\end{array}$ & $\begin{array}{c}\text { English } \\
\text { Rated } \\
\text { Familiarity }\end{array}$ \\
\hline Part of the Human Body & $.94 *$ & $.92 *$ & $.50^{*}$ & $.82 *$ \\
\hline Metal & $.93 *$ & $.97 *$ & $.97 *$ & $.96 *$ \\
\hline Weapon & $.97 *$ & $.97 *$ & $.79 *$ & $.83 *$ \\
\hline Clothing & $.96 *$ & $.94 *$ & $.75^{*}$ & $.88 *$ \\
\hline Cloth & $.92 *$ & $.90^{*}$ & $.87^{*}$ & $.91^{*}$ \\
\hline Color & $.98 *$ & $.95 *$ & $.90^{*}$ & $.86^{*}$ \\
\hline Vehicle & $.95^{*}$ & $.95^{*}$ & $.94 *$ & $.90^{*}$ \\
\hline Part of a Building & $.95 *$ & $.95 *$ & $.87 *$ & $.77 *$ \\
\hline Furniture & $96^{*}$ & $.96 *$ & $.83 *$ & $.96^{*}$ \\
\hline Musical Instrument & $.95^{*}$ & $.97 *$ & $.85^{*}$ & $.86^{*}$ \\
\hline Fruit & $.93 *$ & $.98 *$ & $.90^{*}$ & $.95^{*}$ \\
\hline Bird & $.92 *$ & $.93 *$ & $.98 *$ & $.92 *$ \\
\hline Overall & $.94 *$ & $.95 *$ & $.89^{*}$ & $.91^{*}$ \\
\hline
\end{tabular}




\section{EXPERIMENT 2}

In Experiment 1, the prototypicality gradients of the Spanish- and English-speaking monolinguals were fairly discrepant for a number of categories. In Experiment 2, we examined the degree to which these differences in cultural typicality could be accounted for by differences in familiarity. Cultural familiarity was determined by asking a subset of subjects employed in the typicality study to rate the items on concept familiarity. It was predicted that if familiarity plays a role in determining cultural differences in typicality, then statistically controlling for the effects of cultural familiarity should result in higher interlingual typicality correlations. This should be true particularly for those categories for which there is a wide discrepancy in the typicality gradients for the two language groups.

\section{Method}

Subjects. The subjects were 50 volunteers (from the original 100 subjects) who agreed to participate in a second session. Twentyfive Spanish-speaking (14 males) and 25 English-speaking (12 males) monolinguals served as subjects.

Stimuli and Procedure. Approximately 6 months after they had participated in the typicality rating session, subjects rated the same items used in the original study. The procedure and testing booklets were the same as were used for the typicality ratings, with the exception that the instruction sheet now asked subjects to rate object familiarity within the context of the category. The instructions for the English-speaking subjects were similar to those used by Hampton and Gardiner (1983), with the exception that the poles were reversed and the scale was increased to a 7-point instead of a 5-point scale, with 7 representing highly familiar and 1 representing highly unfamiliar. These instructions were translated into Spanish for the Spanish-speaking subjects as follows:

En las siguientes páginas usted encontrará una colección de palabras agrupadas según la categoria. Hay 12 categorías en total. Su tarea será clasificar su familiaridad con cada artículo en una escala del 1 al 7 . Un 1 indica que la palabra no le es muy familiar, mientras que un 7 significa alta familiaridad. La anotación de un cero (0) será reservada exclusivamente para indicar que la palabra le es desconocida. Probablemente encontrará pocas palabras que desconocerá. Una palabra muy familiar es una en la cual su significado es inmediatamente obvio para usted; pero si el artículo le requiere pausar y pensar, entonces una anotación correspondiendo a poca familiaridad será la apropiada.

Las palabras están agrupadas según su categoría por nuestra con veniencia solamente; fue más fácil listar las palabras categóricamente que por orden alfabético. Por este motivo usted no debe referir al título categórico mientras que lleve a cabo esta tarea. Tampoco deben ser influenciados por la calidad de cada artículo como ejemplar de su categoría. Simplemente clasifique cada artículo dependiendo de la familiaridad que usted tenga del concepto. Finalmente, trate de utilizar todos los números en la escala, es decir, no se afuercen a utilizar solamente los $1 \mathrm{~s}$ y $2 \mathrm{~s}, 0$ los $6 \mathrm{~s}$ y $7 \mathrm{~s}$.

\section{Results and Discussion}

The mean familiarity ratings, along with their associated standard deviations, can be found in the Appendix. To determine the degree of similarity in item familiarity for the two cultures, Pearson product moment correlations of the mean familiarity ratings for the Spanish-English translates were calculated for each category. These can be seen in the second column of Table 1 . These correlations ranged from .21 to .86 , with 9 out of the 12 correlations achieving a significance level of $p<.05$. The reliabilities were calculated as in Experiment 1 and can be seen in Table 2. The reliabilities were generally high with the exception of the category "part of the human body." The likely cause of this relatively low reliability appears to be that most of the Spanish speakers found all of these items quite familiar and gave these items uniformly high ratings, yielding a restrictive range of scores. In any case, the range of the interlingual familiarity correlations indicates that the relative familiarity of the category items varied considerably as a function of cultural group.

Further analyses were performed to compare the degree of correspondence between rated typicality and familiarity for each language group. Correlations between item typicality and familiarity ratings for each group indicated that the degree of the relationship between the two variables was similar for both the Spanish speakers (.47) and the English speakers (.50). The size of this relationship is much closer to the .52 correlation found by Hampton and Gardiner (1983) than to the correlation of .19 noted by Barsalou (1985). As seen in the third and fourth column of Table 1, the typicality-familiarity correlation for each category ranged from -.01 to .88 for English speakers and from -.26 to .91 for Spanish speakers. This compares favorably to the correlation range of .27 to .82 found by Hampton and Gardiner (1983) with a comparable set of materials. Thus, there does seem to be a similar, moderate relationship between familiarity and typicality for these two language groups which resembles that found by other researchers.

A further issue that was addressed by this study is whether differences in the typicality gradients between cultures can be partially accounted for by differences in cultural familiarity with the individual items in the categories. If cultural typicality is related to concept familiarity, it would be expected that each cultural group's typicality ratings would be more highly correlated with that group's cultural familiarity than with the other culture's familiarity with the concepts. An analysis of variance comparing within-culture typicality-familiarity correlations with cross-cultural typicality-familiarity correlations for the categories showed that the mean of the within-culture correlations $(M=.53)$ was higher than that of the cross-cultural correlations $(M=.29)[F(1,11)$ $=20.39, p<.01]$, and that there was no interaction of this variable with language $(F<1)$ or main effect of language $(F<1)$. Another way to address this issue is to statistically control for cultural familiarity and examine the change in the interlingual typicality correlation that results. Specifically, it was predicted that if cultural differences in familiarity are related to differences in typicality, then such a procedure would increase the interlingual typicality correlation. For each language group, we statistically controlled for familiarity by performing a bipartial correlation (Timm \& Carlson, 1976) in which the independent effects of each culture's familiarity with the items were 
removed from the interlingual typicality correlation. This analysis allowed us to investigate the relationship between the Spanish speakers' ratings of typicality and those of the English speakers, while controlling for cultural familiarity. This analysis yielded an overall correlation of .73 $[F(2,674)=389.47, p<.001]$, which accounts for $12.3 \%$ more of the variance than was accounted for before we removed the effects of cultural familiarity; this suggests that discrepancies in familiarity do play a role in reducing intercultural overlap in typicality.

As shown in the last column of Table 1, individual category analyses suggested that controlling for cultural familiarity was particularly successful in increasing the typicality correlation for those categories which previously had large interlingual discrepancies in typicality ("furniture," "musical instrument," "fruit," "bird"). This finding also supports the conclusion that cultural typicality is partially determined by familiarity.

There were only two exceptions to this general pattern. The interlingual typicality correlations for "metal" and "color" were sharply reduced when familiarity was controlled for. As can be seen in the second column of Table 1, the interlingual familiarity correlation is quite high for "metal" (.86) and "color" ( .85$)$, but not nearly so high for any of the other categories. Similarly, the cross-language correlation between typicality and familiarity was highest for these two categories. ${ }^{1}$ Thus, it seems that only in these two categories is there relatively little cross-cultural variation in concept familiarity. As a consequence of these high familiarity correlations, the reduction in interlingual typicality in these two categories cannot be taken as evidence against the view that familiarity is related to cultural differences in typicality.

Finally, the results of this experiment bear on another issue mentioned with regard to the first experiment. As we noted earlier, the most prototypical exemplars for the categories are not the same for both language groups. The question is whether items that form prototypes for one particular group but not for another are more familiar to the group for which they form cultural prototypes. We performed a $t$ test on the unshared prototypical exemplars (i.e., items that were among the five most typical members of the categories for one language group, but not for the other), comparing the familiarity of the items forming cultural prototypical exemplars with the familiarity of those same items when they did not form cultural prototypical exemplars. For example, the English speakers' familiarity with the prototypical bird robin was compared with the familiarity of petirrojo (robin), which is not a prototypical bird for Spanish speakers. We found that these items were more familiar to the culture for which they formed prototypical exemplars of the categories than to the culture for which they did not form prototypical exemplars $[t(33)=2.94, p<.05]$. This finding suggests that familiarity may be partially responsible for determining which items are weighted more heavily in prototype formation.

\section{GENERAL DISCUSSION}

From these two experiments, we can draw several conclusions with regard to the structuring of categories in Spanish- and English-speaking monolinguals. From Experiment 1 , we can conclude that identical typicality gradients cannot be assumed for these two groups, even though their general present environment is controlled for. Moreover, neither can we assume identical prototypical exemplars for these cultures, although similar items are included in extensions of the category terms.

In Experiment 2, familiarity was found to be related to the typicality of members of categories. This was demonstrated in several ways. First, familiarity was found to be similarly correlated with typicality for both Spanish speakers and English speakers. Second, there was an increase in the intercultural typicality correlation when cultural familiarity with the individual items was controlled for. Third, this increase in the intercultural typicality relationship was particularly marked for those categories in which there was a high discrepancy between the cultures in familiarity and typicality. Finally, the items that were prototypical exemplars in only one of the two cultures were rated as being more familiar in the culture for which they were prototypical exemplars than in the other culture. Thus, very high familiarity seems to be essential for prototypical exemplars.

Although the results of Experiment 2 provide evidence for the influence of familiarity on typicality gradients, it is clear that familiarity is not the sole determinant of those gradients. If familiarity were the sole determinant, then it would be expected that the interlingual typicality correlation would be reduced sharply by partialling cultural familiarity. Instead, the interlingual typicality correlation was increased, suggesting that other factors (such as family resemblance, perhaps) also play a role in determining typicality gradients.

Throughout these experiments, differences in ratings between the Spanish- and English-speaking monolinguals have been interpreted as cultural differences. These differences, however, may be due to structural differences in the two languages. Although we cannot rule out this possibility, other evidence suggests that various language subgroups have somewhat divergent typicality gradients. Bjorklund and his colleagues have found divergent typicality gradients in good versus poor readers (Bjorklund \& Bernholtz, 1985), high- versus low-socioeconomicstatus children (Bjorklund \& Weiss, 1985), and younger versus older children (Bjorklund, Thompson, \& Ornstein, 1983). Consequently, identical typicality gradients cannot be assumed for two groups that speak the same language. Nevertheless, our findings of familiarity influences on typicality remain unaffected, regardless of whether those effects are due to language or to culture.

The role of familiarity can be incorporated into many of the existing models of categorization and semantic memory. One common view is that rated typicality is a 
reflection of the family resemblance structure of the category (Rosch \& Mervis, 1975). That is, typicality is viewed as a function of the degree to which members of a category share common properties but are distinct from members of other categories. Our findings suggest that familiarity may mitigate this process. Our results, however, are consistent with the view that typicality varies as a function of distance from prototypical exemplars of the category. This was shown indirectly in Experiment 1 by the finding that, as prototypical exemplars of the category differed between the two cultures, the typicality gradients also differed. The role of familiarity can be incorporated into this model by stating that highly familiar items are more influential in the determination of prototypes. That is, the properties that highly familiar items possess may be more heavily weighted in determining prototypicality. An example of this can be found in our study. For the Spanish-speaking monolinguals, canary is a highly familiar exemplar of "bird." It may be that birds such as parrots and parakeets are viewed as more prototypical because they share the property of demestication with the highly familiar canary; because pigeons do not share this heavily weighted property, they are not seen as prototypical.

In the feature comparison model of Smith et al. (1974), familiarity may be one factor that determines both whether a particular feature enters into the representation of the category term and the relative weight of that feature in the term. Thus, the statement "A canary is a bird" might be verified more slowly for English speakers than for Spanish speakers because either (1) the property (domestication) might not be found in the representation of the category term for English speakers (reducing the assessed similarity between the subject and predicate terms) or (2) the property would be of little weight in the overall decision.

In the marker search model of Glass and Holyoak (1975), familiarity may determine the order of search in determining the truth of a semantic verification statement. This possibility gains support from Hampton and Gardiner (1983), who found a high correlation between production frequency (a variable Glass and Holyoak assumed was related to order of search) and familiarity.

In the context theory of classification of Medin and Schaffer (1978), the familiarity of exemplars may influence both the salience of the exemplar dimensions and the retrievability of exemplars for use in determining the category membership of new items. For example, when a Spanish speaker is attempting to categorize a new bird, the characteristics of domestic birds may more likely be employed in the decision process than they would be for English speakers, because these birds are more readily retrievable for Spanish speakers.

In summary, we have found familiarity to be one determinant of typicality differences between two highly similar cultures. Consequently, it is reasonable to assume that this variable plays a role in determining the goodness of example of category members within a culture.
We do not claim that familiarity is the only determinant of cross-cultural variations in categorization. Rosch (1975b) suggested that organization of category members around different prototypes might be another. Further investigation can distinguish the universality of these ideas.

\section{REFERENCES}

AshCraft, M. H. (1978). Property norms for typical and atypical items from 17 categories: A description and discussion. Memory \& Cognition, 6, 227-232.

Barsalou, L. W. (1985). Average, ideal, and frequency of instantiation as determinants of graded structures in categories. Journal of Experimental Psychology: Learning, Memory, \& Cognition.

Barsalou, L. W., \& SEWEll, D. R. (1984). Constructing representations of categories from different points of view. Emory Cognition Project Report (No. 2), Emory University, Atlanta, GA.

BerLIN, B., \& KAY, P. (1969). Basic color terms: Their universality and evolution. Berkeley: University of California Press.

BjorkLund, D. F., \& Bernholtz, J. E. (1985, April). The role of knowledge base in the memory performance of good and poor readers. Paper presented at the meeting of the Society for Research in Child Development, Toronto.

Bjorklund, D. F., \& Thompson, B. E. (1983). Category typicality effects in children's memory performance: Qualitative and quantitative differences in the processing of category information. Journal of Experimental Child Psychology, 35, 329-344.

Bjorklund, D. F., Thompson, B. E., \& Ornstein, P. A. (1983). Developmental trends in children's typicality judgments. Behavior Research Methods \& Instrumentation, 15, 350-356.

BjoRKLUND, D. F., \& Weiss, S. C. (1985). The influence of economic status on children's classification and free recall. Journal of Educational Psychology, 77, 119-128.

Cole, M., Gay, J., Guick, J. A., \& Sharp, D. W. (1971). The cultural context of learning and thinking. New York: Basic Books.

Duncan, E. M., \& Kellas, G. (1978). Developmental changes in the internal structure of semantic categories. Journal of Experimental Child Psychology, 26, 328-340.

GLASS, A. L., \& HolyoAK, K. J. (1975). Alternative conceptions of semantic memory. Cognition, 3, 313-339.

Glass, A. L., MEANY, P. J. (1978). Evidence for two kinds of low typical instances in a categorization task. Memory \& Cognition, 6, 622-628.

GREenBerG, M. S., \& BJoRkLUND, D. F. (1981). Category typicality in free recall: Effects of feature overlap or differential category encoding? Journal of Experimental Psychology: Human Learning \& Memory, 7, 145-147.

Hampton, J. A., \& Gardiner, M. M. (1983). Measures of internal category structure: A correlational analysis of normative data. British Journal of Psychology, 74, 491-516.

HeIDER, E. R. (1972). Universals in color naming and memory. Journal of Experimental Psychology, 93, 10-20.

Keller, D., Kellas, G. (1978). Typicality as a dimension of encoding. Journal of Experimental Psychology: Human Learning \& Memory, 4, 78-85.

MALT, B. C., \& SmITH, E. E. (1982). The role of familiarity in determining typicality. Memory \& Cognition, 6, 622-628.

MCCLOSKEY, M. (1980). The stimulus familiarity problem in semantic memory research. Journal of Verbal Learning \& Verbal Behavior, 19, 485-502.

MCCloskey, M., \& Glucksberg, S. (1979). Decision processes in verifying category membership statements: Implications for models of semantic memory. Cognitive Psychology, 11, 1-37.

Medin, D. L., \& SCHAFFER, M. M. (1978). Context theory of classification learning. Psychological Review, 85, 207-238.

Medin, D. L., \& Smith, E. E. (1984). Concepts and concept formation. Annual Review of Psychology, 35, 113-138.

Mervis, C. B., Catlin, J., \& Rosch, E. (1976). Relationships among 
goodness-of-example, category norms, and word frequency. Bulletin of the Psychonomic Society, 7, 283-294.

Mervis, C. B., \& Rosch, E. (1981). Categorization of natural objects. Annual Review of Psychology, 32, 89-115.

Posnansky, C. J. (1978). Category norms for verbal items in 25 categories for children in grades 2-6. Behavior Research Methods \& Instrumentation, 10, 819-832.

Rosch, E. (1975a). Cognitive representations of semantic categories Journal of Experimental Psychology: General, 104, 192-233.

Rosch, E. (1975b). Universals and cultural specifics in human categorization. In R. W. Brislin, S. Bochner, \& W. J. Lonner (Eds.), Cross cultural perspectives on learning. New York: Sage.

Rosch, E., \& Mervis, C. B. (1975). Family resemblances: Studies in the internal structure of categories. Cognitive Psychology, 7, 573-605.

Rosch, E. H., Simpson, C., \& Miller, R. S. (1976). Structural bases of typicality effects. Joumal of Experimental Psychology: Human Perception \& Performance, 2, 491-502.
Smith, E. E., Shoben, E. J., \& Rips, L. J. (1974). Structure and process in semantic memory: A featural model for semantic decisions. Psychological Review, 81, 214-241.

Timm, N. H., \& Carlson, J. E. (1976). Part and bipartial canonical correlation analysis. Psychometrika, 41, 159-176.

UyedA, K. M., \& MANDLER, G. (1980). Prototypicality norms for 28 semantic categories. Behavior Research Methods \& Instrumentation, 12, 587-595.

\section{NOTE}

1. The correlation between the English typicality and Spanish familiarity ratings was .87 for "metal" and .55 for "color." The corresponding correlation between the Spanish typicality and English familiarity ratings was .73 for "metal" and .78 for "color."

APPENDIX

Prototypicality Ratings for 12 Semantic Categories in English and Spanish

\begin{tabular}{|c|c|c|c|c|c|c|c|c|c|}
\hline \multirow[b]{2}{*}{ Member (English) } & \multicolumn{2}{|c|}{ Protypicality } & \multicolumn{2}{|c|}{ Familiarity } & \multirow[b]{2}{*}{ Member (Spanish) } & \multicolumn{2}{|c|}{ Protypicality } & \multicolumn{2}{|c|}{ Familiarity } \\
\hline & Mean & $\mathrm{SD}$ & Mean & $\mathrm{SD}$ & & Mean & $\mathrm{SD}$ & Mean & SD \\
\hline & Bird & & & & & Pájaro & & & \\
\hline 1. (3) eagle & 6.52 & .86 & 6.60 & 1.00 & 1. canario & 6.38 & 1.32 & 6.88 & .44 \\
\hline 2. (24) robin & 6.46 & 1.22 & 6.36 & 1.44 & 2. pájaro carpintero & 6.06 & 1.73 & 6.56 & 1.12 \\
\hline 3. (10) cardinal & 6.40 & 1.05 & 5.80 & 2.33 & 3. águila & 5.84 & 1.98 & 6.32 & 1.07 \\
\hline 4. (16) bluebird & 6.40 & 1.23 & 5.72 & 1.40 & 4. golondrina & 5.70 & 1.98 & 5.60 & 1.96 \\
\hline 5. (9) seagull & 6.34 & 1.29 & 6.48 & 1.12 & 5. cotorra & 5.63 & 1.55 & 6.88 & .33 \\
\hline 6. (11) hawk & 6.30 & .99 & 6.08 & 1.17 & 6. gorrión & 5.50 & 2.07 & 6.16 & 1.77 \\
\hline 7. (27) jay & 6.29 & 1.17 & 6.00 & 1.34 & 7. paloma & 5.46 & 1.75 & 6.96 & .20 \\
\hline 8. (7) dove & 6.18 & 1.06 & 5.88 & 1.69 & 8. perico & 5.44 & 1.62 & 6.76 & .66 \\
\hline 9. (2) woodpecker & 6.16 & 1.10 & 6.29 & 1.00 & 9. gaviota & 5.40 & 2.04 & 6.40 & 1.04 \\
\hline 10. (25) blackbird & 6.16 & 1.58 & 5.96 & 1.51 & 10. cardenal & 5.18 & 2.50 & 5.48 & 1.87 \\
\hline 11. (19) pigeon & 6.14 & 1.44 & 6.60 & .91 & 11. halcón & 5.02 & 2.58 & 4.20 & 2.18 \\
\hline 12. (18) crow & 6.12 & 1.27 & 6.52 & .87 & 12. faisán & 5.00 & 2.17 & 6.12 & 1.20 \\
\hline 13. (5) parrot & 6.08 & 1.24 & 6.68 & .63 & 13. cisne & 4.73 & 2.32 & 6.32 & 1.31 \\
\hline 14. (8) parakeet & 6.08 & 1.32 & 6.68 & .90 & 14. cóndor & 4.69 & 2.79 & 3.88 & 2.52 \\
\hline 15. (6) sparrow & 6.06 & 1.36 & 6.24 & 1.23 & 15. colibrí & 4.41 & 2.89 & 3.12 & 2.26 \\
\hline 16. (1) canary & 6.02 & 1.36 & 5.88 & 1.83 & 16. azulejo & 4.39 & 2.93 & 4.24 & 2.51 \\
\hline 17. (4) swallow & 5.94 & 1.66 & 4.72 & 2.03 & 17. lechuza & 4.35 & 2.59 & 6.36 & 1.11 \\
\hline 18. (26) oriole & 5.88 & 1.77 & 4.08 & 2.58 & 18. cue & 4.16 & 2.53 & 4.88 & 2.22 \\
\hline 19. (15) hummingbird & 5.78 & 1.36 & 6.16 & 1.11 & 19. pich & 4.13 & 2.55 & 6.12 & 1.36 \\
\hline 20. (17) owl & 5.64 & 1.44 & 6.60 & 1.12 & 20. gallina & 3.85 & 2.35 & 6.88 & .44 \\
\hline 21. (23) duck & 5.24 & 1.35 & 6.80 & .41 & 21. pollo & 3.76 & 2.27 & 6.92 & .40 \\
\hline 22. (12) pheasant & 5.14 & 1.67 & 4.48 & 2.29 & 22. gayo & 3.66 & 2.32 & 6.92 & .40 \\
\hline 23. (13) swan & 5.04 & 1.62 & 6.36 & 1.19 & 23. pato & 3.54 & 2.47 & 6.84 & .37 \\
\hline 24. (14) condor & 4.96 & 2.39 & 3.24 & 2.47 & 24. petirrojo & 3.29 & 3.10 & 2.16 & 2.29 \\
\hline 25. (22) rooster & 4.88 & 1.62 & 6.68 & .90 & 25. mirlo & 2.77 & 3.05 & 1.72 & 2.28 \\
\hline 26. (21) chicken & 4.80 & 1.80 & 6.80 & .65 & 26. oriol & 2.49 & 2.98 & 1.88 & 1.94 \\
\hline \multirow[t]{2}{*}{ 27. (20) hen } & 4.56 & 1.62 & 6.52 & 1.16 & 27. grajo & .94 & 2.03 & .84 & 1.80 \\
\hline & Fruit & & & & & Finta & & & \\
\hline 1. (1) apple & 6.82 & .56 & & .28 & & 6.52 & 1.11 & 7.00 & .00 \\
\hline 2. (2) orange & 6.76 & .92 & 7.00 & 0.00 & 2. naranja & 6.36 & 1.16 & 7.00 & 0.00 \\
\hline 3. (3) banana & 6.32 & 1.10 & 7.00 & 0.00 & 3. banana & 6.32 & 1.29 & 7.00 & 0.00 \\
\hline 4. (11) peach & 6.30 & 1.18 & 6.32 & 1.38 & 4. pera & 6.16 & 1.28 & 6.88 & .44 \\
\hline 5. (4) pear & 6.22 & 1.22 & 6.28 & 1.51 & 5. piña & 6.02 & 1.51 & 6.96 & .20 \\
\hline 6. (14) grapefruit & 6.20 & 1.29 & 6.56 & 1.42 & 6. mango & 5.96 & 1.44 & 7.00 & 0.00 \\
\hline 7. (13) strawberry & 6.04 & 1.34 & 6.68 & .75 & 7. uva & 5.86 & 1.70 & 7.00 & 0.00 \\
\hline 8. (15) cherry & 5.88 & 1.44 & 6.08 & 1.78 & 8. papaya & 5.78 & 1.49 & 6.61 & .91 \\
\hline 9. (5) pineapple & 5.76 & 1.44 & 6.44 & .87 & 9. melón & 5.70 & 1.36 & 6.80 & .50 \\
\hline 10. (21) apricot & 5.76 & 1.45 & 5.24 & 2.47 & 10. mamey & 5.68 & 2.10 & 6.84 & .80 \\
\hline 11. (9) melon & 5.74 & 1.52 & 6.08 & 1.61 & 11. melocotón & 5.56 & 1.54 & 6.72 & .61 \\
\hline 12. (16) plum & 5.72 & 1.44 & 5.80 & 1.41 & 12. mandarina & 5.46 & 1.64 & 6.88 & .33 \\
\hline
\end{tabular}


APPENDIX (Continued)

\begin{tabular}{|c|c|c|c|c|c|c|c|c|c|}
\hline \multirow[b]{2}{*}{ Member (English) } & \multicolumn{2}{|c|}{ Protypicality } & \multicolumn{2}{|c|}{ Familiarity } & \multirow[b]{2}{*}{ Member (Spanish) } & \multicolumn{2}{|c|}{ Protypicality } & \multicolumn{2}{|c|}{ Familiarity } \\
\hline & Mean & SD & Mean & SD & & Mean & SD & Mean & SD \\
\hline 13. (7) grape & 5.56 & 1.58 & 6.60 & 1.08 & 13. fresa & 5.44 & 2.05 & 6.64 & .95 \\
\hline 14. (20) lemon & 5.34 & 1.83 & 6.44 & 1.16 & 14. toronja & 5.40 & 1.95 & 6.84 & .47 \\
\hline 15. (26) raspberry & 5.28 & 1.58 & 5.00 & 1.61 & 15. cereza & 5.22 & 1.86 & 5.96 & 1.66 \\
\hline 16. (28) lime & 5.02 & 1.85 & 6.04 & 1.43 & 16. ciruela & 4.90 & 2.10 & 6.64 & .70 \\
\hline 17. (6) mango & 4.70 & 1.95 & 5.92 & 1.66 & 17. coco & 4.48 & 2.01 & 6.84 & .37 \\
\hline 18. (8) papaya & 4.16 & 2.00 & 4.08 & 2.60 & 18. tamarindo & 4.44 & 2.14 & 6.28 & 1.46 \\
\hline 19. (30) raisin & 3.98 & 1.61 & 6.52 & .82 & 19. anón & 4.30 & 2.66 & 6.69 & .90 \\
\hline 20. (12) mandarine & 3.98 & 2.49 & 3.16 & 2.14 & 20. limón & 4.18 & 2.46 & 6.88 & .33 \\
\hline 21. (27) prune & 3.82 & 1.73 & 5.04 & 2.30 & 21. albaricoque & 4.12 & 2.21 & 3.92 & 1.85 \\
\hline 22. (23) pomegranate & 3.80 & 1.95 & 3.20 & 2.66 & 22. chirimoya & 4.04 & 2.56 & 5.56 & 2.16 \\
\hline 23. (17) coconut & 3.56 & 1.88 & 6.24 & 1.20 & 23. granada & 3.96 & 2.41 & 4.48 & 2.38 \\
\hline 24. (25) avocado & 3.34 & 1.98 & 5.40 & 2.20 & 24. mamoncillo & 3.92 & 2.53 & 6.52 & 1.09 \\
\hline 25. (29) tomato & 3.02 & 2.24 & 6.60 & 1.08 & 25. aguacate & 3.82 & 2.55 & 6.76 & .72 \\
\hline 26. (31) chayote & 1.88 & 2.39 & 2.56 & 2.62 & 26. frambuesa & 3.74 & 2.50 & 3.88 & 2.09 \\
\hline 27. (24) litchi & 1.34 & 1.87 & 1.64 & 1.61 & 27. ciruela pasa & 3.58 & 2.15 & 6.64 & .70 \\
\hline 28. (18) tamarind & .84 & 1.35 & 1.64 & 2.12 & 28. lima & 3.52 & 2.39 & 6.16 & 1.70 \\
\hline 29. (19) soursop & .56 & 1.51 & 1.20 & 2.24 & 29. tomate & 3.26 & 2.50 & 6.80 & .82 \\
\hline 30. (22) cherimoya & .46 & 1.40 & 1.32 & 2.36 & 30. pasa & 3.20 & 2.11 & 6.48 & .92 \\
\hline 31. (10) mammee & .28 & 1.05 & .68 & 1.91 & 31. chayote & 1.74 & 2.13 & 5.40 & 2.06 \\
\hline
\end{tabular}

\section{Musical Instrument}

1. (2) piano
2. (9) saxophone
3. (7) trumpet
4. (3) guitar
5. (1) violin
6. (10) clarinet
7. (8) flute
8. (12) drum
9. (16) trombone
10. (21) tuba
11. (23) banjo
12. (4) organ
13. (6) harp
14. (19) bass drum
15. (15) bugle
16. (24) oboe
17. (5) accordion
18. (13) bass
19. (17) xylophone
20. (11) cornet
21. (14) bongo drums
22. (20) cymbal
23. (22) jingle bells
24. (18) maracas

$\begin{array}{rrrr}\mathbf{6 . 8 4} & .47 & 6.84 & .62 \\ 6.72 & .57 & 6.16 & 1.65 \\ 6.66 & .80 & 6.76 & .83 \\ 6.64 & .66 & 6.76 & .60 \\ 6.57 & .82 & 6.64 & 1.04 \\ 6.52 & .93 & 6.16 & 1.65 \\ 6.44 & .93 & 6.76 & .60 \\ 6.18 & 1.06 & 6.76 & .66 \\ 6.12 & 1.45 & 6.08 & 1.73 \\ 6.02 & 1.42 & 6.32 & 1.31 \\ 5.92 & 1.38 & 5.92 & 1.85 \\ 5.88 & 1.51 & 6.64 & .91 \\ 5.66 & 1.60 & 6.20 & 1.73 \\ 5.58 & 1.54 & 5.84 & 1.80 \\ 5.53 & 1.60 & 5.36 & 2.16 \\ 5.32 & 2.16 & 4.16 & 2.78 \\ 5.14 & 2.02 & 4.84 & 2.64 \\ 5.14 & 1.95 & 5.44 & 2.02 \\ 5.14 & 1.96 & 5.68 & 2.04 \\ 4.96 & 2.41 & 5.12 & 2.22 \\ 4.55 & 1.99 & 5.72 & 1.88 \\ 4.42 & 1.80 & 5.88 & 2.17 \\ 3.48 & 1.88 & 6.04 & 1.43 \\ 3.37 & 2.27 & 3.24 & 2.82\end{array}$

Furniture

1. (5) chair
2. (1) table
3. (24) couch
4. (2) sofa
5. (3) bed
6. (6) desk
7. (7) armchair
8. (4) rocking chair
9. (13) rocker
10. (8) bureau
11. (28) chest
12. (14) cabinet
13. (15) footstool
14. (18) bookshelf

$\begin{array}{rrrr}6.74 & .66 & 6.92 & .40 \\ 6.72 & .61 & 6.96 & .20 \\ 6.68 & .62 & 6.80 & .50 \\ 6.64 & .85 & 6.88 & .44 \\ 6.46 & .95 & 6.92 & .28 \\ 6.28 & .95 & 6.88 & .44 \\ 6.22 & 1.28 & 6.48 & 1.01 \\ 5.96 & 1.29 & 6.72 & .68 \\ 5.80 & 1.09 & 6.44 & .82 \\ 5.46 & 1.68 & 5.84 & .25 \\ 5.22 & 1.73 & 6.12 & 1.33 \\ 4.78 & 1.92 & 6.40 & 1.04 \\ 4.54 & 1.69 & 6.32 & 1.22 \\ 4.34 & 1.84 & 6.64 & .57\end{array}$

Instrumento Musical

1. violín
2. piano
3. guitarra
4. órgano
5. acordeón
6. arpa
7. trompeta
8. flauta
9. saxofón
10. clarinete
11. corneta
12. tambor
13. bajo
14. bongó
15. clarín
16. trombón
17. marimba
18. maracas
19. tambora
20. platillo
21. tuba
22. cascabel
23. banjo
24. oboe

$\begin{array}{rrrr}6.54 & 2.01 & 6.63 & 1.10 \\ 6.52 & 1.30 & 6.96 & .20 \\ 6.44 & 1.25 & 6.75 & 1.02 \\ 6.22 & 1.54 & 6.38 & 1.44 \\ 5.82 & 1.70 & 6.49 & 1.25 \\ 5.80 & 1.84 & 5.54 & 2.47 \\ 5.64 & 1.71 & 5.88 & 1.75 \\ 5.62 & 1.86 & 6.13 & 1.42 \\ 5.60 & 1.99 & 5.92 & 1.53 \\ 5.50 & 1.87 & 4.58 & 2.19 \\ 5.18 & 1.80 & 6.42 & 1.52 \\ 5.12 & 1.92 & 6.54 & 1.10 \\ 4.68 & 2.19 & 5.21 & 2.02 \\ 4.44 & 2.01 & 6.33 & 1.52 \\ 4.42 & 2.44 & 4.04 & 2.20 \\ 4.26 & 2.26 & 4.46 & 2.23 \\ 4.24 & 2.17 & 5.42 & 2.21 \\ 4.14 & 1.96 & 6.71 & .62 \\ 3.78 & 2.43 & 5.46 & 1.89 \\ 3.60 & 2.21 & 6.21 & 1.20 \\ 2.66 & 2.66 & 3.67 & 2.50 \\ 2.60 & 1.94 & 5.71 & 1.94 \\ 2.56 & 2.73 & 4.54 & 2.59 \\ 2.32 & 2.90 & 3.17 & 2.62\end{array}$

Muebles

1. mesa
2. sofá
3. cama
4. sillón
5. silla
6. escritorio
7. butaca
8. buró
9. alacena
10. vitrina
11. tocador
12. armario
13. mecedora
14. gabinete

$\begin{array}{rrrr}6.58 & .86 & 7.00 & .00 \\ 6.18 & 1.55 & 6.84 & .47 \\ 6.12 & 1.47 & 6.52 & 1.69 \\ 5.88 & 1.48 & 6.96 & .20 \\ 5.78 & 1.87 & 7.00 & .00 \\ 5.46 & 1.68 & 6.84 & .47 \\ 5.38 & 1.96 & 6.92 & .28 \\ 5.30 & 2.07 & 6.59 & 1.02 \\ 4.94 & 2.11 & 5.96 & 1.43 \\ 4.92 & 2.10 & 6.28 & 1.28 \\ 4.92 & 2.14 & 6.12 & 1.51 \\ 4.88 & 2.10 & 6.04 & 1.17 \\ 4.76 & 2.20 & 5.72 & 2.05 \\ 4.70 & 1.90 & 6.24 & 1.56\end{array}$


APPENDIX (Continued)

\begin{tabular}{|c|c|c|c|c|c|c|c|c|c|}
\hline \multirow[b]{2}{*}{ Member (English) } & \multicolumn{2}{|c|}{ Protypicality } & \multicolumn{2}{|c|}{ Familiarity } & \multirow[b]{2}{*}{ Member (Spanish) } & \multicolumn{2}{|c|}{ Protypicality } & \multicolumn{2}{|c|}{ Familiarity } \\
\hline & Mean & SD & Mean & $\mathrm{SD}$ & & Mean & SD & Mean & SD \\
\hline 15. (19) lamp & 3.86 & 1.93 & 6.76 & .60 & 15. banqueta & 4.26 & 2.00 & 6.40 & 1.19 \\
\hline 16. (17) stool & 3.80 & 1.91 & 6.52 & .82 & 16. televisión & 4.26 & 2.38 & 6.96 & .20 \\
\hline 17. (23) piano & 3.78 & 1.61 & 6.52 & 1.01 & 17. taburete & 3.94 & 2.16 & 5.88 & .88 \\
\hline 18. (20) bench & 3.70 & 1.97 & 6.56 & 1.23 & 18. estante & 3.78 & 2.19 & 6.20 & 1.47 \\
\hline 19. (22) divan & 3.70 & 2.82 & 3.88 & 2.64 & 19. lámpara & 3.64 & 2.30 & 6.88 & .60 \\
\hline 20. (10) glass case & 3.54 & 1.99 & 5.56 & 1.81 & 20. banco & 3.48 & 2.12 & 6.60 & 1.00 \\
\hline 21. (9) cupboard & 3.30 & 1.81 & 5.96 & 1.70 & 21. radio & 3.44 & 2.26 & 6.84 & .62 \\
\hline 22. (16) television & 3.22 & 1.95 & 6.76 & .60 & 22. diván & 3.40 & 2.72 & 4.32 & 2.56 \\
\hline 23. (29) stereo & 3.00 & 1.90 & 6.76 & .60 & 23. piano & 3.34 & 2.34 & 6.84 & .62 \\
\hline 24. (21) radio & 2.52 & 1.84 & 6.60 & .82 & 24. canapé & 2.96 & 2.44 & 4.24 & 2.26 \\
\hline 25. (27) rug & 2.50 & 1.61 & 6.48 & 1.01 & 25. repisa & 2.88 & 1.93 & 6.28 & 1.37 \\
\hline 26. (25) shelf & 2.48 & 1.71 & 6.48 & 1.05 & 26. cuadro & 2.46 & 1.84 & 6.72 & .90 \\
\hline 27. (11) boudoir & 2.28 & 2.24 & 2.88 & 2.73 & 27. alfombra & 2.28 & 2.13 & 6.60 & 1.32 \\
\hline 28. (26) picture & 2.14 & 1.43 & 6.56 & 1.16 & 28. cofre & 2.24 & 1.94 & 5.80 & 1.80 \\
\hline 29. (12) closet & 1.80 & 1.41 & 6.40 & 1.19 & 29. fonógrafo & 2.06 & 1.75 & 5.24 & 2.19 \\
\hline
\end{tabular}

A Part of a Building

\begin{tabular}{|c|c|c|c|c|c|c|c|c|c|}
\hline 1. (10) room & 6.96 & 1.05 & 6.96 & .20 & 1. escalera & 6.30 & 1.11 & 6.80 & .50 \\
\hline 2. (4) ceiling & 6.28 & 1.14 & 6.96 & .20 & 2. piso & 6.16 & 1.40 & 6.84 & .37 \\
\hline 3. (5) wall & 6.26 & 1.24 & 6.88 & .44 & 3. elevador & 6.04 & 1.41 & 6.76 & .52 \\
\hline 4. (2) floor & 6.22 & 1.27 & 7.00 & .00 & 4. techo & 6.02 & 1.72 & 6.80 & .58 \\
\hline 5. (21) foundation & 5.98 & 1.72 & 5.92 & 1.44 & 5. pared & 5.86 & 1.59 & 6.56 & .92 \\
\hline 6. (14) door & 5.54 & 1.58 & 6.88 & .61 & 6. pasillo & 5.55 & 1.56 & 6.64 & 1.22 \\
\hline 7. (8) window & 5.40 & 1.64 & 6.91 & .29 & 7. base & 5.96 & 2.31 & 5.72 & 1.75 \\
\hline 8. (1) stairway & 5.38 & 1.28 & 6.58 & 1.06 & 8. ventana & 5.36 & 1.83 & 6.92 & .2 \\
\hline 9. (13) bathroom & 5.24 & 1.57 & 7.00 & .00 & 9. cemento & 5.26 & 2.16 & 6.68 & .7 \\
\hline 10. (6) hallway & 5.12 & 1.72 & 6.80 & .65 & 10. habitación & 5.22 & 1.60 & 6.88 & .33 \\
\hline 11. (20) basement & 4.86 & 1.87 & 6.44 & .95 & 11. viga & 5.06 & 2.36 & 4.92 & 2.10 \\
\hline 12. (19) kitchen & 4.76 & 1.86 & 7.00 & .00 & 12. ladrillo & 5.04 & 1.89 & 6.72 & .8 \\
\hline 13. (26) cornerstone & 4.68 & 2.25 & 5.13 & 2.33 & 13. baño & 4.92 & 2.21 & 6.96 & .2 \\
\hline 14. (11) beam & 4.60 & 2.07 & 5.84 & 1.72 & 14. puerta & 4.78 & 1.93 & 6.96 & .2 \\
\hline 15. (17) corridor & 4.50 & 1.73 & 6.13 & 1.63 & 15. madera & 4.70 & 2.31 & 6.94 & 1.6 \\
\hline 16. (29) attic & 4.46 & 1.98 & 6.35 & 1.23 & 16. oficina & 4.54 & 2.26 & 6.56 & 1.16 \\
\hline 17. (12) brick & 4.44 & 2.06 & 6.57 & .83 & 17. corredor & 4.40 & 2.33 & 5.84 & 1.7 \\
\hline 18. (16) office & 4.38 & 2.07 & 6.72 & .54 & 18. escalón & 4.36 & 2.11 & 6.48 & 1.0 \\
\hline 19. (3) elevator & 4.32 & 2.12 & 6.80 & .50 & 19. cocina & 4.32 & 2.36 & 6.80 & .65 \\
\hline 20. (25) chimney & 4.22 & 2.12 & 6.46 & 1.14 & 20. sótano & 4.26 & 2.18 & 6.16 & 1.63 \\
\hline 21. (9) cement & 4.18 & 2.16 & 6.42 & 1.02 & 21. cimiento & 4.24 & 2.70 & 5.12 & 2.2 \\
\hline 22. (18) step & 4.12 & 1.78 & 6.58 & 1.28 & 22. mampostería & 3.98 & 2.71 & 6.56 & .8 \\
\hline 23. (32) closet & 3.92 & 1.74 & 6.72 & .54 & 23. sala & 3.96 & 2.08 & 6.76 & .6 \\
\hline 24. (15) wood & 3.84 & 2.21 & 6.71 & .86 & 24. vidrio & 3.68 & 2.00 & 6.48 & 1.12 \\
\hline 25. (27) side & 3.80 & 2.29 & 6.22 & 1.24 & 25. chimenea & 3.48 & 2.02 & 6.08 & 1.9 \\
\hline 26. (23) parlor & 3.74 & 1.97 & 5.25 & 1.92 & 26. piedra angular & 3.18 & 2.75 & 3.28 & 2.78 \\
\hline 27. (7) base & 3.66 & 2.40 & 5.61 & 1.75 & 27. costado & 2.90 & 2.35 & 5.88 & 2.26 \\
\hline 28. (28) lights & 3.65 & 2.11 & 6.96 & .21 & 28. faroles & 2.86 & 1.78 & 6.52 & 1.45 \\
\hline 29. (22) masonry & 3.58 & 2.27 & 4.70 & 2.31 & 29. ático & 2.53 & 2.05 & 4.62 & 1.20 \\
\hline 30. (24) glass & 3.46 & 2.11 & 6.87 & .34 & 30. rincón & 2.36 & 1.71 & 6.48 & 1.36 \\
\hline 31. (30) corner & 3.22 & 2.10 & 6.48 & 1.12 & 31. alacena & 2.32 & 2.29 & 4.00 & 2.63 \\
\hline 32. (33) cabinet & 2.96 & 1.54 & 6.57 & .73 & 32. armario & 2.31 & 1.88 & 6.61 & 1.03 \\
\hline 33. (31) cupboard & 2.66 & 1.61 & 6.00 & 1.76 & 33. gabinete & 1.75 & .71 & 6.60 & 1.00 \\
\hline \multicolumn{5}{|c|}{ Vehicle } & \multicolumn{5}{|c|}{ Vehículo } \\
\hline 1. (3) car & 6.94 & .31 & 6.96 & .20 & 1. automóvil & 6.82 & .48 & 6.96 & .20 \\
\hline 2. (2) auto & 6.61 & .93 & 6.76 & .88 & 2. auto & 6.64 & .80 & 6.88 & .4 \\
\hline 3. (1) automobile & 6.58 & 1.42 & 6.88 & .44 & 3. carro & 6.36 & 1.38 & 6.92 & .2 \\
\hline 4. (10) airplane & 6.45 & .97 & 6.96 & .20 & 4. ómnibus & 5.94 & 1.62 & 6.96 & .2 \\
\hline 5. (14) bus & 6.36 & 1.03 & 6.88 & .44 & 5. camioneta & 5.82 & 1.64 & 6.76 & .5 \\
\hline 6. (9) train & 6.23 & 1.05 & 6.76 & .72 & 6. autobús & 5.70 & 1.89 & 6.96 & .2 \\
\hline 7. (8) taxi & 6.00 & 1.59 & 6.80 & .50 & 7. camión & 5.60 & 1.97 & 6.84 & .3 \\
\hline 8. (17) subway & 5.86 & 1.34 & 6.00 & 1.71 & 8. $\operatorname{taxi}$ & 5.60 & 1.97 & 6.96 & .2 \\
\hline 9. (15) motorcycle & 5.76 & 1.49 & 6.88 & .33 & 9. tren & 5.10 & 2.18 & 6.80 & .5 \\
\hline
\end{tabular}


APPENDIX (Continued)

\begin{tabular}{|c|c|c|c|c|c|c|c|c|c|}
\hline \multirow[b]{2}{*}{ Member (English) } & \multicolumn{2}{|c|}{ Protypicality } & \multicolumn{2}{|c|}{ Familiarity } & \multirow[b]{2}{*}{ Member (Spanish) } & \multicolumn{2}{|c|}{ Protypicality } & \multicolumn{2}{|c|}{ Familiarity } \\
\hline & Mean & SD & Mean & SD & & Mean & SD & Mean & SD \\
\hline 10. (5) pick-up truck & 5.74 & 1.41 & 6.80 & .65 & 10. avión & 4.94 & 2.45 & 6.96 & .20 \\
\hline 11. (7) truck & 5.56 & 1.49 & 6.84 & .55 & 11. tranvía & 4.84 & 2.12 & 6.04 & 1.37 \\
\hline 12. (13) ship & 5.28 & 1.81 & 6.52 & 1.12 & 12. coche & 4.84 & 2.24 & 6.40 & 1.35 \\
\hline 13. (22) bicycle & 5.23 & 1.60 & 6.92 & .40 & 13. barco & 4.76 & 2.25 & 6.84 & .37 \\
\hline 14. (24) boat & 5.12 & 1.49 & 6.76 & .52 & 14. guagua & 4.74 & 2.83 & 6.96 & .20 \\
\hline 15. (21) motorbike & 5.12 & 1.69 & 6.28 & 1.17 & 15. motocicleta & 4.50 & 2.31 & 6.76 & .44 \\
\hline 16. (6) autobus & 5.08 & 2.04 & 5.24 & 2.20 & 16. aeroplano & 4.22 & 2.44 & 6.68 & .75 \\
\hline 17. (29) trolley & 4.83 & 1.71 & 5.44 & 1.81 & 17. metro & 4.20 & 2.60 & 6.00 & 1.55 \\
\hline 18. (16) aeroplane & 4.80 & 2.48 & 4.48 & 2.43 & 18. aeronave & 3.98 & 2.47 & 5.72 & 1.60 \\
\hline 19. (11) streetcar & 4.68 & 1.80 & 5.44 & 1.76 & 19. helicóptero & 3.96 & 2.40 & 6.48 & .96 \\
\hline 20. (4) omnibus & 4.56 & 2.50 & 4.16 & 2.43 & 20. motoneta & 3.83 & 2.20 & 6.36 & 1.00 \\
\hline 21. (19) helicopter & 4.32 & 2.03 & 6.28 & 1.65 & 21. moto & 3.62 & 2.42 & 6.24 & 1.59 \\
\hline 22. (20) motorscooter & 4.18 & 1.92 & 6.04 & 1.43 & 22. bicicleta & 3.56 & 2.29 & 6.80 & .50 \\
\hline 23. (25) speedboat & 3.86 & 1.81 & 6.32 & .99 & 23. tractor & 3.46 & 2.42 & 6.48 & 1.16 \\
\hline 24. (31) scooter & 3.81 & 2.06 & 6.04 & 1.37 & 24. bote & 3.34 & 2.21 & 6.84 & .47 \\
\hline 25. (18) airship & 3.78 & 2.25 & 5.00 & 2.14 & 25. lancha & 3.26 & 2.16 & 6.64 & .64 \\
\hline 26. (30) sailboat & 3.70 & 1.72 & 6.68 & .85 & 26. vagón & 2.86 & 2.20 & 5.52 & 2.22 \\
\hline 27. (12) coach & 3.56 & 1.67 & 5.08 & 2.02 & 27. tanque & 2.50 & 2.36 & 5.36 & 1.91 \\
\hline 28. (26) wagon & 2.84 & .82 & 6.36 & 1.08 & 28. patín & 1.74 & 1.94 & 5.96 & 1.95 \\
\hline 29. (23) tractor & 2.54 & 1.88 & 6.52 & 1.16 & 29. trole & 1.56 & 2.31 & 2.80 & 2.72 \\
\hline 30. (28) skates & 2.45 & 1.77 & 6.48 & 1.26 & 30. chalupa & 1.34 & 1.99 & 4.48 & 2.63 \\
\hline 31. (27) tank & 2.16 & 1.53 & 6.08 & 1.75 & 31. monopatín & 1.14 & 1.59 & 3.88 & 3.17 \\
\hline \multicolumn{5}{|c|}{ Colors } & \multicolumn{5}{|c|}{ Colores } \\
\hline 1. (3) blue & 6.98 & .14 & 6.92 & .40 & 1. rojo & 6.50 & 1.15 & 6.96 & .20 \\
\hline 2. (1) red & 6.96 & .20 & 6.88 & .44 & 2. blanco & 6.46 & 1.49 & 6.84 & 1.47 \\
\hline 3. (6) yellow & 6.94 & .24 & 6.92 & .40 & 3. azul & 6.15 & 1.31 & 6.96 & .20 \\
\hline 4. (4) green & 6.66 & .90 & 6.84 & .55 & 4. verde & 6.06 & 1.56 & 6.72 & .84 \\
\hline 5. (13) orange & 6.56 & .86 & 6.64 & .76 & 5. negro & 5.84 & 2.15 & 6.76 & .66 \\
\hline 6. (11) purple & 6.48 & .84 & 6.56 & .77 & 6. amarillo & 5.76 & 1.74 & 6.88 & .60 \\
\hline 7. (14) brown & 6.32 & 1.06 & 6.76 & .72 & 7. gris & 5.72 & 1.80 & 6.52 & 1.09 \\
\hline 8. (8) pink & 5.82 & 1.44 & 6.56 & .82 & 8. rosado & 5.34 & 1.86 & 6.60 & .87 \\
\hline 9. (9) violet & 5.76 & 1.39 & 6.20 & 1.04 & 9. violeta & 5.26 & 1.86 & 6.20 & 1.32 \\
\hline 10. (5) black & 5.74 & 2.03 & 6.94 & .40 & 10. vino & 4.80 & 1.99 & 6.68 & .69 \\
\hline 11. (2) white & 5.64 & 2.11 & 6.92 & .40 & 11. morado & 4.80 & 1.99 & 6.32 & 1.25 \\
\hline 12. (27) dark brown & 5.58 & 1.33 & 6.60 & .76 & 12. crema & 4.78 & 2.00 & 6.32 & 1.31 \\
\hline 13. (18) gold & 5.30 & 1.66 & 6.56 & .82 & 13. anaranjado & 4.52 & 2.21 & 6.64 & .81 \\
\hline 14. (7) gray & 5.30 & 1.93 & 6.52 & .82 & 14. carmelita & 4.48 & 2.44 & 6.84 & .37 \\
\hline 15. (19) silver & 5.14 & 1.86 & 6.39 & .90 & 15. lila & 4.32 & 2.10 & 6.16 & 1.28 \\
\hline 16. (23) scarlet & 5.04 & 1.69 & 5.36 & 1.78 & 16. turquesa & 4.31 & 2.18 & 5.24 & 2.37 \\
\hline 17. (10) burgundy & 5.00 & 1.58 & 6.00 & 1.19 & 17. esmeralda & 4.28 & 2.30 & 5.68 & 2.06 \\
\hline 18. (16) turquoise & 4.92 & 1.72 & 5.28 & 2.01 & 18. dorado & 4.24 & 2.25 & 6.44 & 1.16 \\
\hline 19. (26) crimson & 4.62 & 1.95 & 4.32 & 2.50 & 19. plateado & 4.10 & 2.32 & 6.56 & 1.08 \\
\hline 20. (15) lilac & 4.56 & 1.80 & 5.46 & 1.66 & 20. oliva & 3.58 & 2.37 & 6.32 & 1.03 \\
\hline 21. (29) indigo & 4.56 & 1.82 & 3.72 & 2.53 & 21. bronceado & 3.51 & 2.32 & 6.16 & 1.18 \\
\hline 22. (24) chestnut & 4.46 & 1.40 & 5.44 & 1.45 & 22. ámbar & 3.36 & 2.41 & 4.89 & 2.28 \\
\hline 23. (21) bronze & 4.44 & 1.59 & 5.56 & 1.29 & 23. escarlata & 3.21 & 2.29 & 3.36 & 2.60 \\
\hline 24. (17) emerald & 4.36 & 1.86 & 5.24 & 1.88 & 24. castaño & 2.92 & 2.14 & 6.16 & 1.40 \\
\hline 25. (20) olive & 4.34 & 1.65 & 5.76 & 1.30 & 25. canela & 2.90 & 2.12 & 5.92 & 1.53 \\
\hline 26. (12) cream & 4.26 & 1.60 & 6.00 & 1.38 & 26. carmín & 2.72 & 2.23 & 3.96 & 2.51 \\
\hline 27. (22) amber & 4.22 & 1.73 & 4.96 & 2.01 & 27. moreno & 2.36 & 1.85 & 5.72 & 1.77 \\
\hline 28. (25) cinnamon & 3.72 & 1.68 & 5.20 & 1.78 & 28. azafrán & 2.34 & 2.10 & 4.20 & 2.61 \\
\hline \multirow[t]{2}{*}{ 29. (28) saffron } & 2.74 & 2.08 & 3.60 & 2.61 & 29. índigo & 2.22 & 2.47 & 2.60 & 2.48 \\
\hline & \multicolumn{4}{|l|}{ Cloth } & \multicolumn{5}{|c|}{ Tela } \\
\hline 1. (3) cotton & 6.56 & 1.11 & 6.80 & 5.60 & 1. & 6.52 & 1.22 & 6.60 & 1.26 \\
\hline 2. (5) linen & 6.26 & 1.10 & 6.12 & 1.48 & 2. lana & 6.14 & 1.39 & 6.52 & 1.26 \\
\hline 3. (1) silk & 6.08 & 1.63 & 6.60 & .65 & 3. algodón & 5.60 & 1.70 & 6.76 & .83 \\
\hline 4. (9) flannel & 5.98 & 1.25 & 5.52 & 2.31 & 4. terciopelo & 5.50 & 2.05 & 5.96 & 1.90 \\
\hline 5. (2) wool & 5.88 & 1.57 & 6.60 & .65 & 5. lino & 5.22 & 2.19 & 4.80 & 2.40 \\
\hline 6. (16) satin & 5.56 & 1.70 & 6.24 & 1.01 & 6. pana & 5.14 & 2.19 & 5.76 & 1.92 \\
\hline
\end{tabular}


APPENDIX (Continued)

\begin{tabular}{|c|c|c|c|c|c|c|c|c|c|}
\hline \multirow[b]{2}{*}{ Member (English) } & \multicolumn{2}{|c|}{ Protypicality } & \multicolumn{2}{|c|}{ Familiarity } & \multirow[b]{2}{*}{ Member (Spanish) } & \multicolumn{2}{|c|}{ Protypicality } & \multicolumn{2}{|c|}{ Familiarity } \\
\hline & Mean & $\mathrm{SD}$ & Mean & SD & & Mean & SD & Mean & SD \\
\hline 7. (6) corduroy & 5.50 & 1.90 & 6.04 & 1.95 & 7. jersey & 4.94 & 2.23 & 6.64 & 1.96 \\
\hline 8. (4) velvet & 5.28 & 1.74 & 6.52 & .92 & 8. nylon & 4.78 & 2.26 & 6.60 & .82 \\
\hline 9. (12) cloth & 5.20 & 2.42 & 5.76 & 2.09 & 9. franela & .76 & 2.06 & 5.12 & 2.46 \\
\hline 10. (8) nylon & 4.94 & 1.95 & 6.28 & 1.10 & 10. muselina & 4.62 & 2.42 & 4.72 & 2.57 \\
\hline 11. (11) rayon & 4.86 & 1.93 & 4.76 & 2.40 & 11. rayón & 4.54 & 2.29 & 4.84 & 2.27 \\
\hline 12. (10) muslin & 4.56 & 2.22 & 4.28 & 2.61 & 12. paño & 4.46 & 2.11 & 5.88 & 1.62 \\
\hline 13. (14) canvas & 4.40 & 2.06 & 5.56 & 2.00 & 13. tafetan & 4.18 & 2.67 & 4.80 & 2.58 \\
\hline 14. (7) jersey & 4.04 & 2.19 & 4.44 & 2.60 & 14. lona & .96 & 2.13 & 5.80 & 2.00 \\
\hline 15. (13) taffeta & 4.04 & 2.59 & 3.00 & 3.15 & 15. gasa & 3.88 & 2.16 & 5.72 & 2.07 \\
\hline 16. (15) gauze & 3.98 & 1.90 & 5.40 & 2.16 & 16. raso & 20 & 2.77 & 3.64 & 2.27 \\
\hline 17. (17) crepe & 3.88 & 2.18 & 4.04 & 2.37 & 17. crespón & .02 & 2.54 & 3.08 & 2.43 \\
\hline 18. (18) mohair & 3.30 & 2.13 & 3.04 & 2.97 & 18. moer & 1.96 & 2.67 & 2.88 & 2.91 \\
\hline \multicolumn{5}{|c|}{ Clothing } & \multicolumn{5}{|c|}{ Ropa } \\
\hline 1. (2) pants & 6.94 & .31 & 6.92 & .40 & 1. vestiuo & 6.38 & 1.16 & 6.80 & .71 \\
\hline 2. (3) shirt & 6.94 & .31 & 6.88 & .44 & 2. pantalones & 4 & 1.39 & 7.00 & .00 \\
\hline 3. (4) blouse & 6.78 & .55 & 6.72 & .74 & 3. camisa & 6.28 & 1.14 & 7.00 & .00 \\
\hline 4. (1) dress & 6.76 & .59 & 6.80 & .58 & 4. blusa & 6.16 & 1.58 & 6.56 & 1.04 \\
\hline 5. (5) skirt & 6.68 & .77 & 6.68 & .75 & 5. falda & 5.72 & 1.81 & 6.48 & 1.16 \\
\hline 6. (9) sports coat & 5.88 & 1.21 & 6.32 & 1.15 & 6. traje & 5.48 & 1.61 & 6.92 & .40 \\
\hline 7. (6) suit & 5.86 & 1.46 & 6.72 & .61 & 7. abrigo & 5.28 & 1.70 & 6.68 & .85 \\
\hline 8. (8) sweater & 5.84 & 1.23 & 6.72 & .84 & 8. suéter & 5.22 & 1.49 & 6.64 & .81 \\
\hline 9. (17) shorts & 5.76 & 1.38 & 6.88 & .33 & 9. cha & 4.92 & 1.79 & 6.28 & 1.28 \\
\hline 10. (10) underwear & 5.65 & 1.58 & 6.76 & .72 & 10. calzoncillo & 4.86 & 2.03 & 6.76 & .72 \\
\hline 11. (12) dress coat & 5.54 & 1.31 & 6.08 & 1.15 & 11. zapato & 4.80 & 2.33 & 6.92 & .40 \\
\hline 12. (7) overcoat & 5.42 & 1.57 & 6.20 & 1.38 & 12 & 4.64 & 2.09 & 6.76 & .83 \\
\hline 13. (11) shoe & 5.24 & 1.86 & 6.64 & .90 & 13. medias & 4.56 & 2.01 & 6.80 & .65 \\
\hline 14. (14) socks & 5.22 & 1.77 & 6.72 & .84 & 14. calcetín & 4.24 & 2.19 & 5.76 & 2.24 \\
\hline 15. (21) slip & 4.94 & 1.82 & 6.64 & .76 & 15. calzones & 2 & 2.32 & 5.96 & 1.70 \\
\hline 16. (19) under & 4.80 & 2.00 & 6.36 & 1.38 & 16. corbata & 3.88 & 1.97 & 6.72 & .84 \\
\hline 17. (18) vest & 4.72 & 1.97 & 6.52 & .96 & 17. calzones c & & 2.30 & 5.84 & 1.75 \\
\hline 18. (22) swimsuit & 4.40 & 1.95 & 6.76 & .60 & 18. & 4 & 2.04 & 6.28 & 1.34 \\
\hline 19. (23) belt & 4.36 & 1.70 & 6.76 & .83 & ams & 3.76 & 1.94 & 6.64 & .81 \\
\hline 20. (13) stockings & 4.02 & 1.94 & 6.28 & 1.37 & 20 faia & 3.56 & 2.32 & 6.24 & .48 \\
\hline 21. (27) hat & 4.0 & 2.08 & 6.68 & .90 & ajo & 4 & 2.20 & 5.92 & 1.80 \\
\hline 22. (16) tie & 4.00 & 1.87 & 6.44 & .87 & 2. & 38 & 2.12 & 6.72 & .68 \\
\hline 23. (28) glove & 4.00 & 1.94 & 6.64 & 1.15 & 23. c & 2.96 & 1.85 & 6.64 & .81 \\
\hline 24. (25) scarf & 3.9 & 2.00 & 6.28 & 1.4 & & & 2.31 & 6.20 & 1.29 \\
\hline 25. (15) breeches & 3.96 & 2.10 & 5.32 & 1.2 & 2 & & 1.69 & 6.20 & 1.41 \\
\hline 26. (24) slip & 3.5 & 1.99 & 6.32 & 1. & & & 1.85 & 5.80 & 1.79 \\
\hline 27. (26) shawl & 3.44 & 1.83 & 5.64 & 2.14 & EIC & 0 & 1.74 & 6.40 & 1.32 \\
\hline 28. (20) girdle & 3.08 & 1.96 & 6.08 & 1.44 & & .38 & 1.70 & 6.20 & 1.58 \\
\hline 29. (29) handkerchief & 2.32 & 1.74 & 6.52 & 1.30 & 29. & 2.14 & 1.60 & 6.12 & 1.62 \\
\hline \multicolumn{5}{|c|}{ Weapon } & \multicolumn{5}{|c|}{ Arma } \\
\hline 1. (4) gun & & .59 & 6.8 & .4 & & 6.55 & 1.32 & 5.60 & 1.80 \\
\hline 2. (3) pistol & & .63 & 6.6 & .7 & & & 1.48 & 6.44 & 1.16 \\
\hline 3. (5) rifle & 6.52 & .74 & 6.64 & 1.00 & 3. $\mathrm{p}$ & 6.37 & 1.52 & 6.16 & 1.46 \\
\hline 4. (2) revolver & 6.50 & .81 & 5.56 & 2.29 & 4. fusil & 6.10 & 1.74 & 5.24 & 2.13 \\
\hline 5. (9) shotgun & 6.4 & .93 & 6.68 & .75 & 5. rifle & 5.92 & 1.79 & 5.68 & 1.65 \\
\hline 6. (1) machine gun & 6.42 & 1.28 & 6.60 & .82 & 6. cañó & 5.60 & 1.78 & 6.36 & 1.35 \\
\hline 7. (11) bomb & 6.30 & 1.09 & 6.04 & 1.94 & 7. granada & 5.56 & 1.92 & 5.08 & 1.87 \\
\hline 8. (18) knife & 6.1 & 1.27 & 6.96 & .20 & 8. bayoneta & 5.48 & 2.20 & 4.56 & 2.24 \\
\hline 9. (6) canno & 5.92 & 1.21 & 5.64 & 2.10 & 9. e & 5.40 & 2.00 & 6.16 & 1.34 \\
\hline 10. (14) missile & 5.88 & 1.76 & 5.56 & 2.12 & 10. bazuca & 5.29 & 2.48 & 4.36 & 2.43 \\
\hline 11. (17) sword & 5.72 & 1.44 & 5.88 & 1.94 & 11. bomba & 5.25 & 2.23 & 5.08 & 2.31 \\
\hline 12. (7) grenade & 5.44 & 2.29 & 5.44 & 2.20 & $12 t$ & 4.58 & 2.18 & 5.88 & 1.54 \\
\hline 13. (10) bazooka & 5.40 & 1.88 & 3.96 & 2.59 & 13.0 & 4. & 2.18 & 3.48 & 2.04 \\
\hline 14. (12) $\tan \mathrm{k}$ & & 1.5 & 6.16 & 1.82 & & 4.23 & 2.60 & 4.16 & 2.48 \\
\hline 15. (8) bayonet & 5.28 & 2.00 & 4.08 & 2.71 & 15. navaja & 4.10 & 2.15 & 6.40 & 1.23 \\
\hline 16. (19) arrow & 4.46 & 1.66 & 6.16 & 1.68 & 16. lanza & 4.08 & 2.25 & 6.04 & 1.43 \\
\hline
\end{tabular}


APPENDIX (Continued)

\begin{tabular}{|c|c|c|c|c|c|c|c|c|c|}
\hline \multirow[b]{2}{*}{ Member (English) } & \multicolumn{2}{|c|}{ Protypicality } & \multicolumn{2}{|c|}{ Familiarity } & \multirow[b]{2}{*}{ Member (Spanish) } & \multicolumn{2}{|c|}{ Protypicality } & \multicolumn{2}{|c|}{ Familiarity } \\
\hline & Mean & SD & Mean & $\mathrm{SD}$ & & Mean & SD & Mean & SD \\
\hline 17. (16) lance & 3.92 & 2.35 & 3.60 & 2.60 & 17. espada & 4.00 & 2.26 & 6.40 & 1.32 \\
\hline 18. (20) hatchet & 3.90 & 1.69 & 6.16 & 1.31 & 18. cuchillo & 3.69 & 2.37 & 6.52 & 1.19 \\
\hline 19. (13) dynamite & 3.86 & 2.08 & 5.96 & 1.70 & 19. flecha & 3.65 & 2.20 & 6.36 & 1.38 \\
\hline 20. (24) fist & 3.78 & 1.93 & 6.76 & .76 & 20. hacha & 3.43 & 2.15 & 6.44 & 1.33 \\
\hline 21. (15) jackknife & 3.69 & 1.94 & 5.68 & 1.98 & 21. mano & 3.08 & 2.33 & 6.40 & 1.58 \\
\hline 22. (27) whip & 3.60 & 1.94 & 6.20 & 1.47 & 22. veneno & 2.67 & 2.16 & 4.72 & 2.48 \\
\hline 23. (22) poison & 3.18 & 2.15 & 6.24 & 1.56 & 23. automóvil & 2.59 & 2.33 & 6.52 & 1.30 \\
\hline 24. (26) chain & 3.04 & 1.84 & 6.32 & 1.52 & 24. puño & 2.51 & 2.13 & 5.96 & 2.15 \\
\hline 25. (32) rope & 2.96 & 1.97 & 6.56 & 1.16 & 25. palo & 2.47 & 1.87 & 6.32 & 1.52 \\
\hline 26. (25) stick & 2.70 & 1.56 & 6.44 & 1.36 & 26. cadena & 2.40 & 1.70 & 6.24 & 1.54 \\
\hline 27. (31) hammer & 2.64 & 1.82 & 6.48 & 1.16 & 27. látigo & 2.26 & 1.67 & 6.28 & 1.31 \\
\hline 28. (30) rock & 2.40 & 1.65 & 6.56 & 1.16 & 28. piedra & 2.27 & 1.75 & 6.44 & 1.42 \\
\hline 29. (21) hand & 2.34 & 1.77 & 6.72 & .98 & 29. hoz & 2.27 & 2.21 & 4.12 & 2.52 \\
\hline 30. (28) stone & 2.12 & 1.53 & 6.40 & 1.44 & 30. roca & 2.06 & 1.68 & 6.36 & 1.44 \\
\hline 31. (23) automobile & 2.02 & 1.76 & 6.36 & 1.58 & 31. martillo & 2.02 & 1.60 & 6.48 & 1.42 \\
\hline 32. (29) sickle & 1.80 & 1.47 & 4.56 & 2.62 & 32. soga & 1.92 & 1.50 & 6.32 & 1.49 \\
\hline \multicolumn{3}{|c|}{ Metal } & & & \multicolumn{3}{|c|}{ Metales } & & \\
\hline 1. (3) steel & 6.84 & .82 & 6.68 & .80 & 1. oro & 6.52 & 1.28 & 6.92 & .40 \\
\hline 2. (8) iron & 6.80 & .57 & 6.72 & .46 & 2. plata & 6.34 & 1.22 & 6.84 & .47 \\
\hline 3. (4) copper & 6.60 & .70 & 6.64 & .86 & 3. acero & 6.14 & 1.51 & 6.56 & 1.12 \\
\hline 4. (14) tin & 6.34 & .87 & 6.48 & .92 & 4. cobre & 5.96 & 1.40 & 6.44 & 1.45 \\
\hline 5. (2) silver & 6.28 & 1.25 & 6.84 & .47 & 5. bronce & 5.94 & 1.50 & 5.92 & 1.98 \\
\hline 6. (1) gold & 6.28 & 1.37 & 6.92 & .28 & 6. aluminio & 5.90 & 1.59 & 6.28 & 1.67 \\
\hline 7. (9) lead & 6.10 & 1.13 & 6.00 & 1.87 & 7. platino & 5.90 & 1.82 & 6.20 & 1.26 \\
\hline 8. (6) aluminum & 6.10 & 1.53 & 6.72 & .54 & 8. hierro & 5.78 & 1.81 & 6.68 & .99 \\
\hline 9. (5) bronze & 5.74 & 1.63 & 5.40 & 2.02 & 9. plomo & 5.76 & 1.70 & 5.88 & 1.97 \\
\hline 10. (11) nickel & 5.68 & 1.46 & 6.24 & 1.05 & 10. cromo & 5.40 & 1.92 & 5.72 & 2.37 \\
\hline 11. (7) platinum & 5.66 & 1.53 & 4.76 & 2.26 & 11. niquel & 5.30 & 1.93 & 5.24 & 2.07 \\
\hline 12. (16) magnesium & 4.60 & 1.78 & 3.64 & 2.38 & 12. cinc & 4.62 & 2.46 & 4.24 & 2.42 \\
\hline 13. (12) zinc & 4.40 & 2.03 & 5.20 & 2.18 & 13. mercurio & 4.42 & 2.43 & 4.56 & 2.06 \\
\hline 14. (15) uranium & 4.08 & 2.11 & 3.80 & 2.65 & 14. lata & 4.41 & 2.34 & 6.24 & 1.45 \\
\hline 15. (10) chromium & 4.02 & 2.40 & 3.96 & 2.69 & 15. uranio & 4.38 & 2.59 & 3.04 & 2.19 \\
\hline 16. (13) mercury & 3.62 & 2.11 & 5.92 & 1.26 & 16. magnesio & 4.14 & 2.57 & 4.16 & 2.25 \\
\hline 17. (17) manganese & 3.56 & 2.15 & 2.40 & 2.47 & 17. manganeso & 3.76 & 2.58 & 3.20 & 2.22 \\
\hline 18. (19) titanium & 3.22 & 2.39 & 2.08 & 2.34 & 18. cobalto & 3.66 & 2.58 & 3.12 & 2.17 \\
\hline 19. (18) cobalt & 2.96 & 1.97 & 3.16 & 2.81 & 19. titanio & 3.58 & 2.70 & 2.32 & 2.12 \\
\hline 20. (23) cadmium & 2.68 & 2.48 & 2.16 & 2.48 & 20. potasio & 3.56 & 2.39 & 3.88 & 2.40 \\
\hline 21. (20) potassium & 2.48 & 1.66 & 4.24 & 2.51 & 21. calcio & 3.48 & 2.58 & 4.24 & 2.24 \\
\hline 22. (21) calcium & 2.16 & 1.67 & 5.68 & 2.06 & 22. sodio & 3.36 & 2.34 & 3.36 & 2.50 \\
\hline 23. (22) sodium & 2.08 & 1.68 & 5.08 & 2.22 & 23. cadmio & 2.56 & 2.64 & 2.28 & 2.34 \\
\hline
\end{tabular}

A Part of the Human Body

$\begin{array}{llllllllll}\text { 1. (1) head } & 6.86 & .41 & 6.96 & .20 & \text { 1. cabeza } & 6.90 & .30 & 6.88 & .44 \\ \text { 2. (3) leg } & 6.78 & .55 & 7.00 & .00 & \text { 2. brazo } & 6.66 & .72 & 6.88 & .33 \\ \text { 3. (5) hand } & 6.76 & .69 & 6.92 & .28 & \text { 3. pierna } & 6.40 & 1.05 & 6.84 & .62 \\ \text { 4. (2) arm } & 6.64 & .78 & 7.00 & .00 & \text { 4. pie } & 6.34 & 1.15 & 6.92 & .28 \\ \text { 5. (4) foot } & 6.48 & .93 & 6.88 & .44 & \text { 5. mano } & 6.32 & 1.38 & 6.96 & .20 \\ \text { 6. (7) mouth } & 6.04 & 1.37 & 6.92 & .28 & \text { 6. espalda } & 6.18 & 1.29 & 6.80 & .82 \\ \text { 7. (9) heart } & 5.98 & 1.27 & 6.48 & .96 & \text { 7. boca } & 6.10 & 1.33 & 7.00 & .00 \\ \text { 8. (14) ear } & 5.96 & 1.14 & 6.84 & .47 & \text { 8. cuello } & 6.08 & 1.35 & 6.64 & .81 \\ \text { 9. (17) shoulder } & 5.92 & 1.34 & 6.76 & .63 & \text { 9. corazon } & 6.08 & 1.55 & 6.84 & .47 \\ \text { 10. (6) back } & 5.88 & 1.38 & 6.76 & .60 & \text { 10. pecho } & 6.04 & 1.38 & 6.64 & .86 \\ \text { 11. (16) eye } & 5.82 & 1.41 & 6.96 & .20 & \text { 11. cerebro } & 6.02 & 1.68 & 6.88 & .44 \\ \text { 12. (10) chest } & 5.82 & 1.44 & 6.76 & .52 & \text { 12. cara } & 5.96 & 1.55 & 6.84 & .80 \\ \text { 13. (8) neck } & 5.78 & 1.46 & 6.84 & .55 & \text { 13. dedo } & 5.94 & 1.42 & 6.84 & .62 \\ \text { 14. (13) finger } & 5.78 & 1.56 & 6.88 & .60 & \text { 14. oído } & 5.92 & 1.48 & 6.84 & .37 \\ \text { 15. (11) brain } & 5.76 & 1.55 & 6.60 & .91 & \text { 15. pulmón } & 5.92 & 1.51 & 6.60 & .96 \\ \text { 16. (23) knee } & 5.62 & 1.56 & 6.80 & .65 & \text { 16. ojo } & 5.84 & 1.65 & 6.88 & .44 \\ \text { 17. (19) nose } & 5.60 & 1.55 & 6.88 & .44 & \text { 17. hombro } & 5.80 & 1.51 & 6.68 & .85 \\ \text { 18. (12) face } & 5.60 & 1.59 & 7.00 & .00 & \text { 18. cadera } & 5.78 & 1.72 & 6.56 & 1.04\end{array}$


APPENDIX (Continued)

\begin{tabular}{|c|c|c|c|c|c|c|c|c|c|}
\hline \multirow[b]{2}{*}{ Member (English) } & \multicolumn{2}{|c|}{ Protypicality } & \multicolumn{2}{|c|}{ Familiarity } & \multirow[b]{2}{*}{ Member (Spanish) } & \multicolumn{2}{|c|}{ Protypicality } & \multicolumn{2}{|c|}{ Familiarity } \\
\hline & Mean & $\mathrm{SD}$ & Mean & SD & & Mean & $\mathrm{SD}$ & Mean & SD \\
\hline 19. (21) stomach & 5.60 & 1.62 & 6.56 & .82 & 19. nariz & 5.76 & 1.56 & 6.76 & .66 \\
\hline 20. (20) ankle & 5.46 & 1.71 & 6.76 & .83 & 20. tobillo & 74 & 1.72 & .68 & .75 \\
\hline 21. (18) hips & 5.38 & 1.63 & 6.60 & .87 & 21. estómag & 5.72 & 1.85 & 6.56 & .96 \\
\hline 22. (25) elbow & 5.28 & 1.83 & 6.80 & .58 & 22. hígado & 5.70 & 1.74 & 6.72 & .61 \\
\hline 23. (26) tongue & 5.14 & 1.82 & 6.80 & .65 & 23. rodilla & 5.62 & 1.59 & 6.68 & \\
\hline 24. (15) lung & 5.04 & 1.87 & 6.32 & .99 & 24. gargant & 5.56 & 1.89 & 6.52 & 1.09 \\
\hline 25. (22) liver & 4.94 & 1.91 & 5.96 & 1.49 & 25. codo & 5.53 & 1.57 & 6.68 & .90 \\
\hline 26. (24) throat & 4.84 & 1.90 & 6.56 & 1.08 & 26. lengua & 5.22 & 2.38 & 6.80 & .50 \\
\hline 27. (27) calf & 4.70 & 1.83 & 6.16 & 1.11 & torrilla & 4.86 & 2.21 & 6.56 & .87 \\
\hline 28. (29) hair & 4.10 & 2.04 & 6.92 & .40 & 28. diente & 4.42 & 2.27 & 6.76 & .72 \\
\hline 29. (28) tooth & 3.80 & 2.14 & 6.76 & 1.01 & 29. pelo & 4.08 & 2.02 & 6.76 & .72 \\
\hline 30. (30) nail & 3.46 & 2.12 & 6.60 & 1.26 & 30. uña & 4.02 & 2.16 & 6.64 & 1.15 \\
\hline
\end{tabular}

(Manuscript received April 5, 1985;

revision accepted for publication September 9, 1985.) 